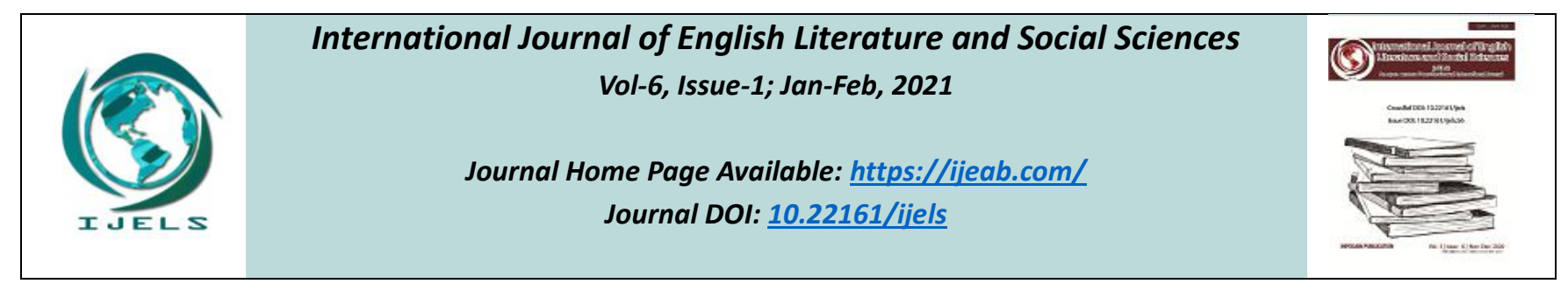

\title{
Research on the Impact of Global Production Segmentation on the Income of Economic Competencies
}

\author{
Sicheng Meng
}

Central University of Finance and Economics, School of International Economics and Trade, 39 South College Road, Haidian, District, Beijing, P. R. China

Received: 30 Oct 2020; Received in revised form: 06 Jan 2021; Accepted: 16 Jan 2021; Available online: 08 Feb 2021

(C2021 The Author(s). Published by Infogain Publication. This is an open access article under the CC BY license (https://creativecommons.org/licenses/by/4.0/).

\begin{abstract}
This paper investigates the role of global production segmentation for the income of economic competencies (ECS) such as design, brand name, organizational capital at the country level for 29 countries from World Input-Output Database (WIOD) over 2000-2014. This study distinguishes various forms of production segmentation and examines how various integrated forms contribute to countries'gain of ECs.This paper finds that production lengthbased on forward industrial linkage (plvg) is positively correlated with value appropriation ofECs in global value chain $(G V C)$, while production length based on backward industrial linkage (plyg)exhibits an opposite effect on the value creation of ECs. Based on whether production happens in domestic factories or foreign partners, this paper finds that the positive effect of plvg on ECs originates from the extension of international production portion, while the domestic production dominates the negative impact of plyg on ECs.
\end{abstract}

Keywords-Global Production Segmentation, Forward and backward production length, Economic Competencies, Value added appropriation.

\section{INTRODUTION}

Due to the decline in transportation costs and digitalization, multinational corporations in industrialized countries are increasingly dividing their production activities and using the comparative advantages formed by capital and technology to specialize in the high value-added production stages in global value chain (GVC). Developing countries utilize cheaper labor costs and latecomer advantages to attract foreign investment to achieve rapid productivity growth. Knowledge or technical capabilities are often cited as key drivers of a company's competitive advantage and GVC has been largely cited as an important channel for companies to access to advanced and new technologies. However, what is being largely neglected is the impact of GVC on the investment and value-added appropriation of brand name, organizational capital, training et al., namely economic competencies (ECs) defined by Corrado et al. (2005), especially the use of econometric analysis to study the relationship between them.

Existing research shows that the reduction of import tariffs enables companies to obtain more diversified 
intermediate inputs or gain better quality intermediate inputs for the same price, which in turn lower the margin cost of production and allows companies to invest more resources to $\mathrm{R} \& \mathrm{D}$ and performance-enhancing capital (Acharya and Keller, 2009; Goldberg et al., 2010). Then early negligible marginal cost and scalable property of those capitals enables their owners to gain benefits from patents, designs, and brands in different stages in GVC without direct investment (Fu, 2018). The study of Durand and Milberg (2018) found that while global value chain increased substantially in the 1990s, industrialized countries set stricter intellectual property protection standards in bilateral and multilateral trade agreements to maintain their monopoly power on knowledge and technology to ensure they can price higher royalty fee to the users of their intellectual property products (IPPs). As global R\&D resources are still highly concentrated in a few industrialized countries (OECD, 2017; World Bank, 2017), the creation of new technologies and knowledge is still the prerogative of a small number of developed countries. The monopoly in innovation and production enables these countries to extract extra economic rents through "unequal exchange" (Ricci, 2019; Rikap and Lundvall, 2019).

Different from existing research, this paper uses country-level data to empirically examine the impact of international trade on the income of ECs, especially from the perspective of production segmentation in GVC. Accurately estimating the income of economic competitiveness assets is crucial for the understanding of gain from trade as well as the decision-making of resource allocation and trade policies faced by companies and countries with different development and resource situation.

With the refinement of the division of labor in the global value chain, companies or countries may make decisions on investment in different forms of assets based on the stage and the integration method they belong to. Therefore, in an increasingly globalized world, we need not only the information about the impact of different value chain integration methods on the returns of $R \& D$ investment, data and other intellectual property products, but also information on that of ECsto understand a more comprehensive picture of the impact of GVC on the returns of intangible assets.

Although the return of ECsis an important indicator to measure the international competitiveness of an economy, little is known about the evolution of its scale for the world economy because ECs such as organizational capital, brand, design and other economic competency assets are usually enterprise-specific and don't circulate in any transaction market.Thismake it impossible to accurately obtain the stock and price of those assets, and it is even more difficult to gainprecise stock and price data at the national level. Therefore, for calculating the income of ECs at the country level, scholars usually estimate it by calculating the residual of value added that goes to neither labor nor mearsured capital in national account or companies' account (Karabarbounis and Neiman, 2018; Barkai, 2020).

One of the main purposes of this paper is to analyze the changes in the income distribution of ECs, so that we can intuitively judge whether the competitiveness of developing countries in terms of brand, organizational assets and design has achieved convergence to developed countries. Secondly is to analyze the role of GVC in the global redistribution of income of ECs, and to explore the impact of different value chain integration forms on ECs. The rest of this study is structured as follows. Section 2 introduces the measurement method of ECs and data sources and provide some descriptive evidence on the redistribution of the return of ECs. Section 3describes empirical strategy; Section 4presents econometric results and discussion on endogeneity. Section 5 provides some robust tests and Section 6 concludes.

\section{EMPIRICAL STRATEGY AND DATA INTRODUCTION}

\subsection{Calculatingthe return of economic competencies}

The estimation method of ECs can be found in Karabarbounis and Neiman (2018) and is presents as equation (1):

$$
\operatorname{Ecom}_{s t}=Y_{s t}-\omega_{s t} L_{s t}-R_{s t} P_{s t} K_{s t}
$$

In equation (1), Ecom $_{s t}$ denotes the return of ECs of country $s$ and year $t, Y_{s t}$ represents countries' gross 
value added, $\omega_{s t} L_{s t}$ denotes total labor costs, $R_{s t} P_{s t} K_{s t}$ is the return of tangibles and IPPs. All these variables are in nominal value terms and have been changed into real terms using price deflators of 2000. Specifically, the calculation method of $R_{s t}$ in this paper is the same as Barkai (2020) and is as equation (2):

$$
R_{s t}=I_{s t}-E_{s t}+D_{s t}
$$

In equation (2), $D_{s t}$ represents depreciation rate, $E_{s t}$ denotes expected inflation rate, and $I_{s t}$ is the nominal interest rate.

2.2 The production length based on forward and backward industrial linkage

The production length of GVC can be divided into production length based on forward industrial linkage $(P l v f)$ and production length based on backward industrial linkage $(P l y f)$. The larger the value of $P l v f$, the more processing stages a primary input from a country-sector inducing in a particular production in GVC. Similarly, the higher the value of Plyf, the fewer production stages occur after an intermediate input enter into a specific country-sector. Plvf can be further decomposed into domestic portion $(d p f)$ and international portion (ipf) based on where the processing stages occur; similarly, Plyf can also be decomposed into domestic portion $(d p b)$ and international portion (ipb). The estimation details of these indicators can be found in Wang et al. (2017), they used World Input-output Table (WIOT) from WIOD to construct indicators like GVC production length, GVC participation degree et al. for 56 industries of 43 major entities and the rest of the world and share these data in the UIBE GVC Indicators database.

\subsection{The database}

The data span of this paper is from 2000 to 2014, involving the integration of multiple databases. The first dataset is the Penn World Table (hereinafter PWT), which providesphysical capital and IPPs, employment population, price index et al. PWT is the main dataset for calculating the return of tangible capital and IPPs, and control variable labor costs. The second main database is the UIBE GVC Indicators database (hereinafter UGI) and provides industry-level GVC production length to estimate national-levelGVC-related indicators for this research. Other databases of this paper to construct control variables include: Federal Reserve Economic Data (FRED), which is the main source of data on 10-year government bond yields of various countries; World Bank (WB), which provides data on $\mathrm{R} \& \mathrm{D}$ expenditure and dependence of foreign direct investment; World Development Index database (WDI) provides institutional quality data; financial development indicator comes from the International Monetary Fund (IMF).

A list of all variables and their definition is reported in Appendix 1.

\subsection{Descriptive analysis}

Before starting econometric analysis, I first provide an overview of the evolution of income share of ECs for the top eight countries with largest $R \& D$ expenditure ${ }^{(1}$, arranged by decreasing net export in 2016 as $\mathrm{Fu}$ and Ghauri (2020) did. Using ratio but not absolute term can help readers to understand the position of ECs in income distribution and this is also better for readers to compare the ECs returns based on countries' economic size.

\footnotetext{
(1) Lack of data for RUS in 2000 and the whole series for Brazil, these two countries rank 10 and 9 in among the figure 2 countries.
} 


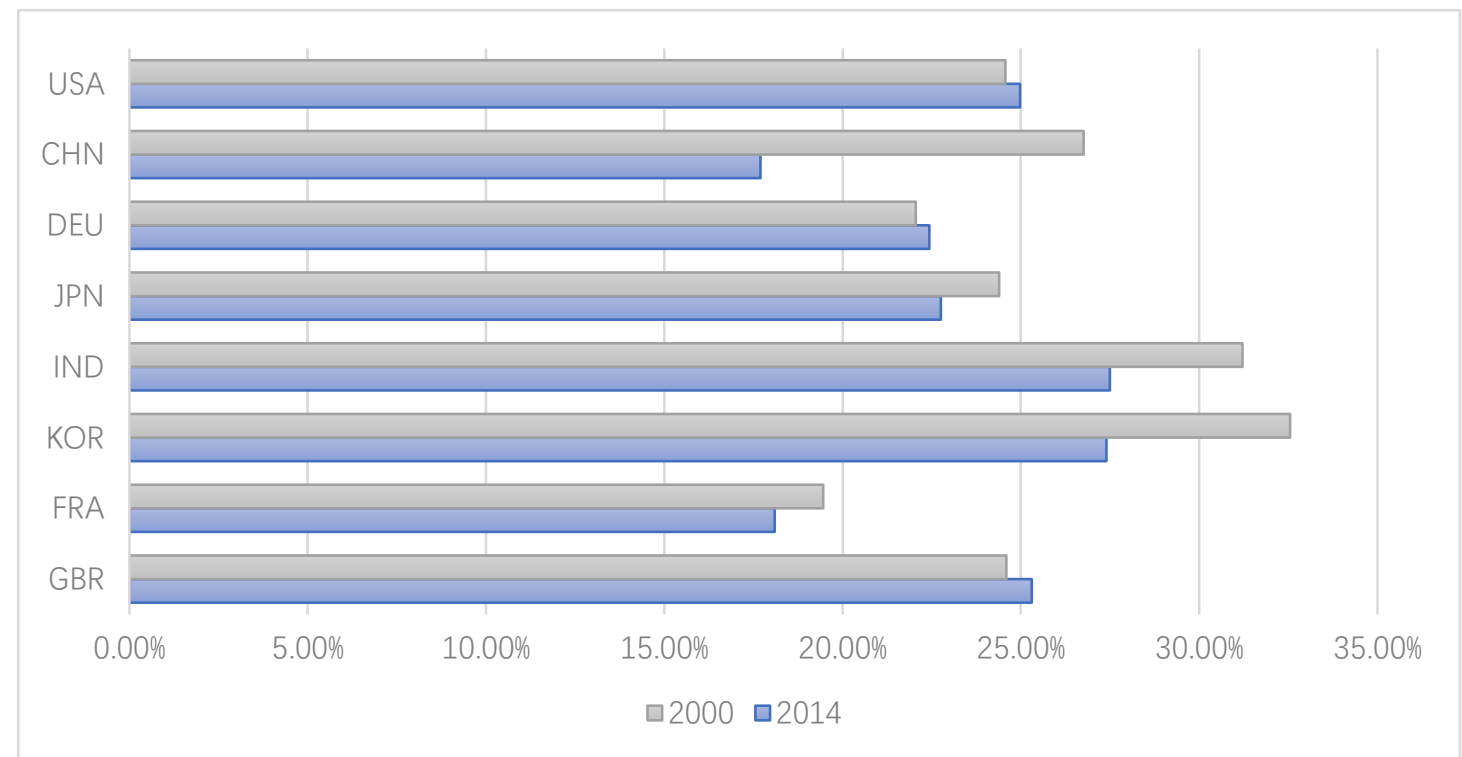

Fig.1: The share of ECs income to GDP for top eight countries with the highest R\&D expenditure in 2016. Source: Autor's estimation.

Figure 1shows the share of ECs income to GDP for top nine countries with the highest $R \& D$ expenditure in 2016. As Figure 2 shows, all developing countries witnessed a downward trend in the share of $\mathrm{ECs}^{2}$, while on average that of ECs in developed countries increased during the same period. Therefore, the ECs income of developing countries had not converged to developed countries during the period.

\section{EMPIRICAL STRATEGY}

Based on the above analysis, this research constructs the following econometric model to examine the impact of production segmentation on the return of ECs:

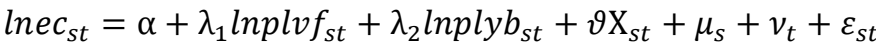

In equation (3), the subscripts $s$ and year $t$ have the same meaning as equation (1); $\operatorname{lne}_{s t}$ represents the logarithm of the ECs income at the national level.

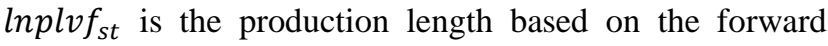
industrial linkage; $\operatorname{lnply} b_{s t}$ denotes production length based on backward industrial linkage. $\mathrm{X}_{s t}$ is the set of control variables of country's specific characteristics that may affect the income of ECs; $\mu_{s}$ and $v_{t}$ represent

(2) RUS ECs income share also decrease in 2014 compared to the corresponding figure in 2004 which is the earliest data we gained in this paper. individual and time fixed effects, respectively; $\varepsilon_{s t}$ is the random error term. All the production length variables are in logarithmic form.

\section{ECONOMETRIC RESULTS}

\subsection{Analysis of benchmark regression}

Thepanel data is unbalanced. After Huasman's test and auxiliary regression estimation for equation (1) with the unbalanced data, the estimation results significantly reject the random effects model. Therefore, the regression results below only show the econometric results of global production segmentation on ECs income in fixed effect model.

(3) Colunm (1) of Table 1 reports the impact of plvf and $p l y b$ on the income of ECs. The regression results show that for every $1 \%$ increase in $p l v f$, the income of ECs increases by $0.846 \%$, whileplyb has no statistically significant impact on the ECs. This shows that the different ways of integrating into the global value chain have heterogeneous effects on the income of ECs. The longer the $p l v f$, the more favorable the growth of the income of ECs. This resultis in line with the finding in $\mathrm{Fu}$ and Ghauri (2020), that is, brand, organizational capital, and design can receive huge profits by embedding more production along GVC. However, the import complexity 
of intermediate products does not affect the income of economic competitiveness assets, which is different to the expectation of this paper the result of other paper. We think that some key variables may be omitted in equation (1) resulting in measurement problem in the regression results. The instrumental variables and robustness tests will be used to further confirm whether the effect exist or not. In order to further analyze the impact of different integrated forms in GVC on the income of ECs, this paper divides $p l v f$ and $p l y b$ into domestic and international portion according to the place where the processing occurs, to analyze the effects of domestic and international production segmentation on ECs income.

Column (2) shows that the domestic and international portion of the global value chain's production division have a heterogeneous effect on the income of ECs. To be more specifically, the extension of $p l v f^{\prime} s$ domestic portion $(d p f)$ significantly reduces the ECs income, while the effect of $p l v f^{\prime} s$ international portion (ipf) is opposite to $d p f$.Because the total effect of $p l v f$ on ECs income is positive, the $d p f^{\prime} s$ effect on ECs income is larger than $i p f^{\prime} s$.The possible explanation is that, in intermediate input export, the requirements for organization and communication skills required for domestic production division and cooperation are relatively low as well as the costs of information searching, which reduces the investment in branding and personnel training and increase. The increase of $d p f$ makes companies or factories prefer to upgrade production equipment and invest in $R \& D$ to improve competitiveness in more competitive domestic market to attract processing activities from domestic companies. In contract, when ipf becomes larger, local intermediate input export companies need to invest more in advertisement to improve brand influence, and in market research and training to better manage downstream companies in GVCto reduce operational risks and maximize profits. More downstream production stages also increase the company's incentives for investment in ECs since these kinds of assets are very low marginal costs and more scalable than tangible assets (Fu, 2018). The effects of the plyb's domestic portion $(d p b)$ and international ( $i p b$ )are completely opposite to $d p f$ and $i p f$, although the effect of the ipb on the income of ECs is not statistically significant. Similar to the conclusion of Marcolin et al. (2017), the increase in the degree of backward value chain embedding enables enterprises to obtain higher quality and technology content intermediate inputs, requiring enterprises to increase their organizational capabilities and communication capabilities to adjust production to the new inputs.

We have analyzed the influence of $p l v f$ and plybas well as their domestic and international portion impact on the income of ECs. However, different countries'plv $f$ and plybarequite different. For instance, China has the longest plvf and plyb in the world. However, Figure 1 shows us that China did not enjoy the largest ECs income share among the top eight countries with highest R\&D expenditure but was the smallest one.How can we use the two directions of production segmentation information to judge whether the participation in GVC has promoted the accumulation of ECs income as a whole? Using the method provide by Wang et al. (2017), this paper estimates the ratio of plvf to $p l y b$ to measure the relative distance to represent a country's position in GVC. The larger the indicator, the more upstream of an economy in GVC. Since $p l v f$ is equal to $p l y b$ at the global level, the position of GVC (gvcpos) can accurately measure the ranking of a country in GVC, which is helpful for us to analyze the difference of the overall integration of GVC on the ECs income.

Column (3) in Table 1 shows that the higher the position in GVC, the higher ECs income. To quote the example of China again, we can expect that even though China has the world's most complex export processing chain for intermediate goods, it may still gain relatively lower ECs income because of the longest processing stages before imported intermediated inputs arriving at Chinese companies. 
Table.1: The Impact of Different GVC Integration Forms on the Income of ECs

Variables lnec

(2)

(3)

\begin{tabular}{|c|c|c|c|}
\hline \multirow[t]{2}{*}{ lnplvf } & $.846 * *$ & & \\
\hline & $(.391)$ & & \\
\hline \multirow[t]{2}{*}{ lnplyb } & -.557 & & \\
\hline & $(.413)$ & & \\
\hline \multirow[t]{2}{*}{$\operatorname{lndpf}$} & & $-.543 * * *$ & \\
\hline & & $(.204)$ & \\
\hline \multirow[t]{2}{*}{$\operatorname{lnipf}$} & & $.62 * * *$ & \\
\hline & & $(.218)$ & \\
\hline \multirow[t]{2}{*}{$\operatorname{lndpb}$} & & $.849 * * *$ & \\
\hline & & $(.228)$ & \\
\hline \multirow[t]{2}{*}{$\operatorname{lnipb}$} & & -.523 & \\
\hline & & $(.348)$ & \\
\hline \multirow[t]{2}{*}{ lngvcpos } & & & $1.459 *$ \\
\hline & & & $(.746)$ \\
\hline C.V. & Yes & Yes & Yes \\
\hline Time FE and Country FE & Yes & Yes & Yes \\
\hline Observations & 418 & 418 & 418 \\
\hline R-squared & .998 & .998 & .998 \\
\hline
\end{tabular}

Note: Control Variables include labor productivity, research and development expenditure, institute quality, ratio of foreign direct investment to gross domestic production, financial development, tangible capital and intellectual property production stock and cost of employees. So, C.V. means these control variables hereafter. Robust standard errors in parentheses. Source: authors' calculations.

\subsection{Discussion on Endogeneity}

The research of Marcolin et al. (2017) had discussed that reverse causality may lead to endogenous problems on analyzing the relationship between GVC participation and investment in ECs. We refer to their research and use one-year lag of all GVC indicators in Table 1 as instrumental variables to re-estimate equation (1) with GMM. The regression results in GMM are reported in Table 2. The main difference between the regression results of Table 2 and Table 1 lies in three aspects. First of all, plybbecomes statistically significant and its sign is still negative, indicating that plyb actually inhibits the growth of ECs income. The possible reason is that the import of more technological or high-quality intermediate products may result insubstitution of in-house production, which in turn reduces the requirements for organization and communication capabilities in production. This result is similar to the finding of Marcolin et al. (2017). Secondly, the sign of $\operatorname{lndpf}$ is still negative but not statistically significant, indicating that the domestic processing of intermediate exports does not affect the income of ECs. Finally, the coefficient of lnipbis statistically significantly negative, representing that increase in the international processing of imported intermediate products will reduce 
the income of ECs. Combined with Marcolin et al. (2017), I assume that in the backward GVC, foreign processing is more likely to substitute the domestic production in imported countries. The substitution effect reduces the investment of enterprises in ECs. In contract, the domestic processing portion of imported intermediate products requires enterprises to increase more investment in ECsto improve management and communication capabilities. Generally, the use of instrumental variables does not affect the interpretation of the results in benchmark regression.

Table 2: GMM Fixed Effect Regression to explain ECs, 2000-2014

Variables lnec

(1) (2)

(3)

\begin{tabular}{|c|c|c|c|}
\hline lnplvg & $\begin{array}{c}1.545^{* * *} \\
(.538)\end{array}$ & & \\
\hline lnplyg & $\begin{array}{c}-1.102 * \\
(.636)\end{array}$ & & \\
\hline $\operatorname{lndpf}$ & & $\begin{array}{l}-.228 \\
(.297)\end{array}$ & \\
\hline $\operatorname{lnipf}$ & & $\begin{array}{l}.722 * * \\
(.297)\end{array}$ & \\
\hline lndpb & & $\begin{array}{l}.628 * \\
(.351)\end{array}$ & \\
\hline lnipb & & $\begin{array}{l}-.798 * \\
(.461)\end{array}$ & \\
\hline $\operatorname{lngvcpos}$ & & & $\begin{array}{c}2.648 * * \\
(1.097)\end{array}$ \\
\hline C.V. & Yes & Yes & Yes \\
\hline Time FE and Country FE & Yes & Yes & Yes \\
\hline Kleibergen-Paap rk LM & 91.397 & 83.159 & 83.112 \\
\hline & $(0.0000)$ & $(0.0000)$ & $(0.0000)$ \\
\hline Kleibergen-Paap rk F & 204.602 & 74.009 & 361.370 \\
\hline & $(16.38)$ & $(16.38)$ & $(16.38)$ \\
\hline Observations & 392 & 392 & 392 \\
\hline R-squared & .814 & .832 & .813 \\
\hline
\end{tabular}

Note: Due to space limitations, the results of the first stage regression are not reported here; when using instrumental variable regression, transitional identification test and weak instrumental variable test were performed. The Sargan test significantly rejected the null hypothesis of over-recognition; Kleibergen-Paap rk LM statistics and Kleibergen -Paap rk F statistic below the square brackets are the $\mathrm{P}$ value and the critical value at the $10 \%$ statistical significance level. The results show that the instrumental variables used in this paper are acceptable. 


\section{ROBUSTNESS CHECK}

The estimation of ECs income is affected by the choice of rental rate of capital and depreciation rate. Excessive depreciation rate will lead to overestimation of capital share and underestimation of ECs income, while underestimation of real interest rates will be the opposite. Since the PWT database already provides country-specific depreciation rates, this paper uses the short-term lending interest rate data from FRED and exploiting higher actual interest rates to re-estimate the income of ECs in order to eliminate the negative impact of the measurement error of capital costs on the benchmark conclusions. Refer to the research of Li and Tang (2003) and Chen et al. (2018), this paper uses short-term nominal lending interest rates to replace the 10-year treasury bond yield rate and pre-set real interest rate of $3 \%$, respectively, to re-estimate the capital rental rate and ECs income, the trends of rental rate of capital estimated by different methods are shown in Figure 2 .

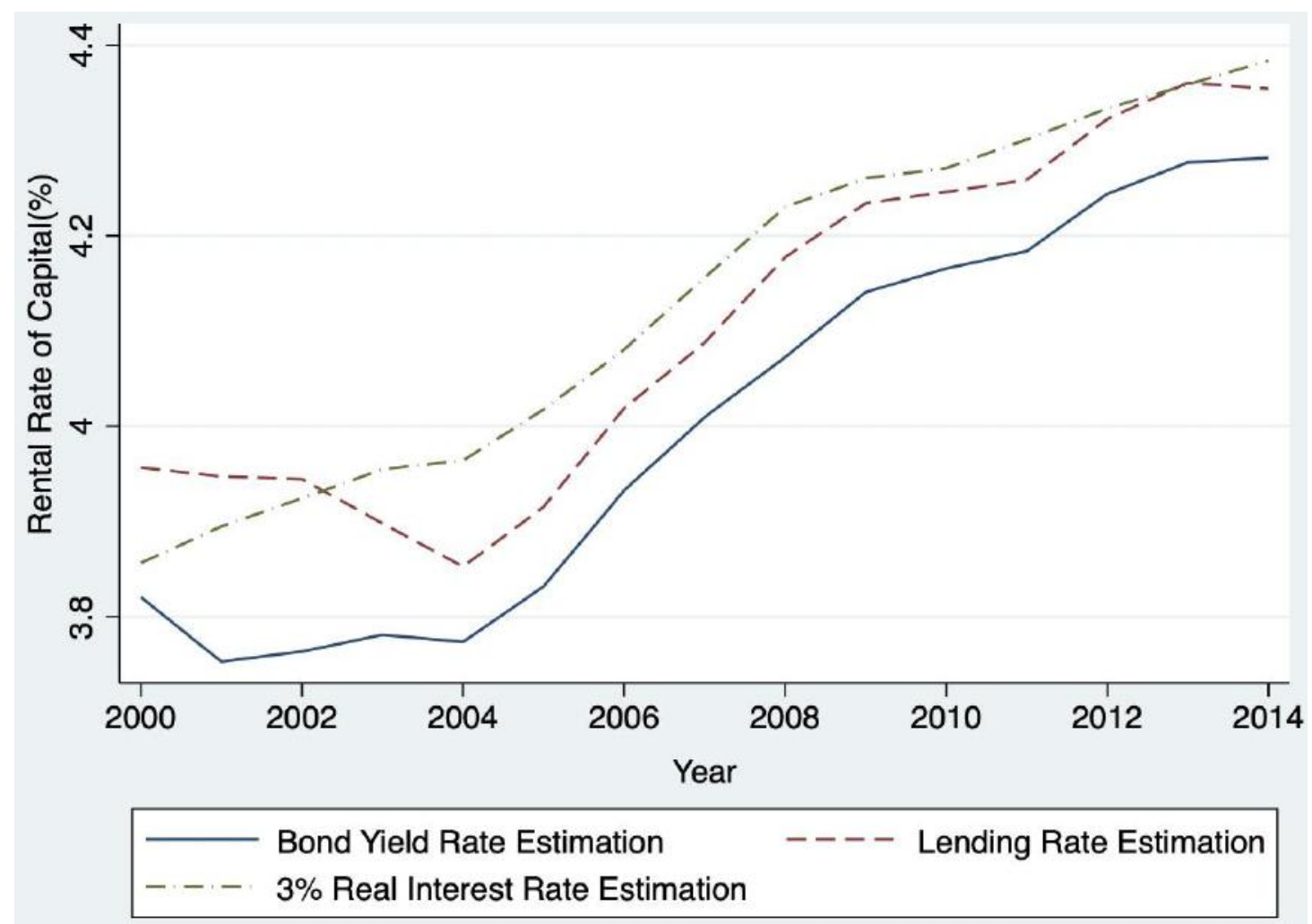

Fig.2: The trend of the world average rental rate of capital using different estimation methods. Source: Autor's estimation.

Higher capital rental rates can be seen as compensation for risk premiums and asset liquidity, which can further alleviate the concern questioned by Karabarbounis and Neiman (2018) that using risk-free interest rates to calculate the cost of capital may lead to an overestimation of ECs income. If there are significant regression differences between the indicators of GVC on the income effects of ECs calculated by different methods, then the previous analysis conclusions cannot be considered to be robust.

Using the short-term nominal lending interest rate (lneclr) and 3\% real interest rate (lnecd) to replace the 10-year treasury bond yield rate to calculate the ECsand re-estimate the equation (1), the regression results are reported in Table 3. The regression results show that, except for coefficients of $\operatorname{lndpf}$ in columns (2) and (5) of Table 3, which has become statistically insignificant, all of the regression results are not significantly different from the benchmark regression, which shows that different ECs income calculation methods does not affect the analysis of the results of benchmark regression in this paper. Therefore, the conclusion of the benchmark regression on the effect of different global value chain integration forms on the income effect of ECs income is robust and credible 
Table 3: Robustness test: Changing the Estimation Method of ECs Income

\begin{tabular}{|c|c|c|c|c|c|c|}
\hline Variables & $\begin{array}{r}\text { Ineclr } \\
\text { (1) }\end{array}$ & $\begin{array}{r}\text { lneclr } \\
\text { (2) }\end{array}$ & $\begin{array}{r}\text { lneclr } \\
\text { (3) }\end{array}$ & $\begin{array}{r}\text { lnecd } \\
\text { (4) }\end{array}$ & $\begin{array}{r}\text { lnecd } \\
(5)\end{array}$ & $\begin{array}{r}\text { Inecd } \\
(6)\end{array}$ \\
\hline \multirow[t]{2}{*}{ lnplvg } & $2.241 * * *$ & & & $1.43^{* * *}$ & & \\
\hline & $(.392)$ & & & $(.367)$ & & \\
\hline \multirow[t]{2}{*}{ lnplyg } & $-1.445 * * *$ & & & $-1.169 * * *$ & & \\
\hline & $(.408)$ & & & $(.374)$ & & \\
\hline \multirow[t]{2}{*}{ lndp } & & .182 & & & .178 & \\
\hline & & $(.235)$ & & & $(.219)$ & \\
\hline \multirow[t]{2}{*}{$\operatorname{lnip}$} & & $1.612 * * *$ & & & $.785^{* *}$ & \\
\hline & & $(.283)$ & & & $(.311)$ & \\
\hline \multirow[t]{2}{*}{$\operatorname{lndpb}$} & & .258 & & & .235 & \\
\hline & & $(.307)$ & & & $(.277)$ & \\
\hline \multirow[t]{2}{*}{ lnipb } & & $-.836 * *$ & & & $-.994 * * *$ & \\
\hline & & $(.369)$ & & & $(.341)$ & \\
\hline \multirow[t]{2}{*}{ lngvcpos } & & & $4.068 * * *$ & & & $2.697 * * *$ \\
\hline & & & $(.729)$ & & & $(.66)$ \\
\hline C.V. & Yes & Yes & Yes & Yes & Yes & Yes \\
\hline Time FE and Country FE & Yes & Yes & Yes & Yes & Yes & Yes \\
\hline Observations & 470 & 470 & 470 & 563 & 563 & 563 \\
\hline R-squared & .998 & .998 & .998 & .997 & .997 & .997 \\
\hline
\end{tabular}

\section{CONCLUSION}

This paper explores the impact of various forms of integrating into the global value chain on the income of economic competencies. Economic competencies income is estimated using the combined data from Penn World Table, World Bank, and Federal Reserve Economic Data etc., and the global production segmentation indicators is based on UIBE GVC Indicators.

The marginal contribution of this paper is to use the method of Karabarbounis and Neiman (2018) to estimate the economic competencies income of 29 countries from 2000 to 2014, and to explore the impact of different integration forms in GVC on the economic competencies' income from the perspective of global production segmentation. Compared with Marcolin et al. (2017) using the "narrow" concept of global value chain's backward industrial linkage participation as indicators of global value chain integration, this research uses the production length of the forward and backward value chains to more fully reflect the participation mode of the economy and the relative upstream degree of in GVC among countries. This provides a deeper understanding of the specific forms of integrating into the GVC and their heterogeneity effect on the income ECs. The results of this paper found that the influence of the production length of the forward value chain and the production length of the backward value chain on the income of ECs is heterogeneous. A longer production length based on forward industrial linkage increases the income of ECs, while the effect of is the opposite to the backward production length, indicating that the more complex the export processing process of intermediate goods, the more conducive to the accumulation of ECs income, while the more complex the 
production process of imported intermediate inputs inhibits the value creation of ECs as a whole. By dividing the production segmentation into domestic portion and international portion according to the place of production, this paper finds that the positive effect of the forward production length on the income of ECs mainly comes from the international portion, which is similar to the finding of $\mathrm{Fu}$ and Ghauri (2020) that the international segmentation of production enables ECs to achieve larger scale economy in more production stages. In the benchmark regression, the domestic portion of export of intermediate goods has a negatively statistically significant effect on the income of ECs. However, the use of instrumental variables and robustness tests make this paper unable to confirm the existence of the negative effect of $d p f$.

In contrast, although the backward production length in the benchmark regression does not have the statistically significant effect onECs income, the use of instrumental variable and robustness tests support its negative effect on ECs income. At the same time, after decomposing the backward production length into domestic and international portion, the regression results from GMM and robustness checks all support the existence of the negative effects of the backward production length on ECs income in that the increase in the complexity of the import production process of intermediate goods has significantly inhibited the growth of ECs income, while international portion of backward production length do not have a significant positive effect. Therefore, the statistically significant effect of domestic portion dominates the overall effect of backward production length on ECs. This finding is consistent with the research found by Marcolin et al. (2017), that is, domestic and foreign outsourcing will reduce investment in organizational capital and software at the same time, and buying intermediate products from other domestic suppliers to replacein-house production will reduce the requirements of organizational capital and software capabilities. Using the position of GVC to reflect the comprehensive effect of the production length of the forward and backward on the income of ECs at the same time, it is found that a greater increase in the forward production length than in backward production length is the key to increasing the income of ECs.

To conclude, firms' or countries' participation forms in GVC significantly determine whether they can realize their ECs income or not. Companies or countries should rationally use international and domestic resources to maximize trade gains based on their own comparative advantages and value chain participation methods.

Appendix 1. Definition of the variables

Table A1

\begin{tabular}{|c|c|c|}
\hline Name of the variable & Definition & Source \\
\hline $\operatorname{lnec}$ & ECs estimated by 10 -year treasury bond rate (natural log) & PWT et al. \\
\hline lneclr & ECs estimated by short-term lending rate (natural log) & PWT et al. \\
\hline lnecd & ECs estimated by $3 \%$ real interest rate (natural log) & PWT et al. \\
\hline lnplvf & Production length based on forward linkage (natural log) & UGI \\
\hline lnplyb & Production length based on backward linkage (natural log) & UGI \\
\hline $\operatorname{lndp}$ & Domestic portion of plvf (natural log) & UGI \\
\hline $\operatorname{lnip}$ & International portion of plvf (natural log) & UGI \\
\hline $\operatorname{lndpb}$ & Domestic portion of plyb (natural log) & UGI \\
\hline $\operatorname{lnipb}$ & International portion of plyb (natural log) & UGI \\
\hline lngvcpos & plvf/plyb (natural log) & UGI \\
\hline lnlabp & Labor productivity (natural log) & PWT \\
\hline
\end{tabular}


$\operatorname{lnacrd}$

Research and development flow (natural log)

rol2001

Rule of laws

WB

lnfdepen

Foreign direct investment stock to GDP (natural $\log$ )

WDI

fd1

Financial development indicators

IMF

$\operatorname{lnk}$

Tangible and IPPs stock (natural $\log$ )

PWT

\section{REFERENCES}

[1] Karabarbounis L, Neiman B. Accounting for Factorless Income. 24404, National Bureau of Economic Research, 2018.

[2] De Loecker J, Eeckhout J. Global market power. National Bureau of Economic Research, 2018.

[3] World Development Report 2019: The Changing Nature of Work. World Bank. /2020-12-14. https://www.worldbank.org/en/publication/wdr2019.

[4] Brandt L, Van Biesebroeck J, Wang L, et al., WTO Accession and Performance of Chinese Manufacturing Firms. American Economic Review, 2017, 107(9): 2784-2820.

[5] Wang Z, Wei S-J, Yu X, et al., Characterizing Global Value Chains: Production Length and Upstreamness. 23261, National Bureau of Economic Research, 2017.

[6] 2018, 34(08): 11-29.

[7] Peltzman S. Industrial Concentration under the Rule of Reason. The Journal of Law and Economics, 2014, 57(S3): S101-S120.

[8] Kulick R. Horizontal Mergers, Prices, and Productivity. Ph. D. Thesis, University of Maryland, 2016.

[9] Grullon G, Larkin Y, Michaely R. Are US industries becoming more concentrated? Review of Finance, 2019, 23(4): 697-743.

[10] Autor D, Dorn D, Katz L F, et al., Concentrating on the Fall of the Labor Share. American Economic Review, 2017, 107(5): 180-185.

[11] De Loecker J, Eeckhout J, Unger G. The rise of market power and the macroeconomic implications. The Quarterly Journal of Economics, Oxford University Press, 2020, 135(2): 561-644.

[12] Corrado C, Hulten C, Sichel D. Intangible Capital and U.s. Economic Growth. Review of Income and Wealth, 2009, 55(3): 661-685.
[13] Bernard A B, Fort T C. Factoryless Goods Producing Firms. American Economic Review, 2015, 105(5): 518-523.

[14] Fontagné L, Harrison A. The Factory-Free Economy: Outsourcing, Servitization and the Future of Industry. w23016, National Bureau of Economic Research, 2017.

[15] Corrado C, Haltiwanger J, Sichel D. Measuring Capital in the New Economy. University of Chicago Press, 2005.

[16] Corrado C, Haskel J, Jona-Lasinio C, et al., Innovation and intangible investment in Europe, Japan, and the United States. Oxford Review of Economic Policy, 2013, 29(2): 261-286.

[17] Farhi E, Gourio F. Accounting for macro-finance trends: Market power, intangibles, and risk premia. National Bureau of Economic Research, 2018.

[18] Caballero R J, Farhi E, Gourinchas P-O. Rents, Technical Change, and Risk Premia: Accounting for Secular Trends in Interest Rates, Returns on Capital, Earning Yields, and Factor Shares. 23127, National Bureau of Economic Research, 2017.

[19] Halpern L, Koren M, Szeidl A. Imported Inputs and Productivity. The American Economic Review, American Economic Association, 2015, 105(12): 3660-3703.

[20] Aristei D, Franco C, Castellani D. Firms' Exporting and Importing Activities: Is there a Two-way Relationship?. Review of World Economics, 2013, 149.

[21] Holmes T J, Jr J A S. A gain from trade: From unproductive to productive entrepreneurship§. Journal of Monetary Economics, 2001: 30.

[22] Manova K, Zhang Z. Multi-Product Firms and Product Quality. w18637, National Bureau of Economic Research, 2012.

[23] Driffield N, Love J, Taylor K. Productivity and Labour Demand Effects of Inward and Outward FDI on UK Industry. 2008.

[24] Bitzer J, Kerekes M. Does foreign direct investment transfer technology across borders? New evidence. 
Economics Letters, 2008, 100(3): 355-358.

[25] Manova K, Yu Z. How firms export: Processing vs. ordinary trade with financial frictions. Journal of International Economics, 2016, 100: 120-137.

[26] Kuhlmann K, Francis T, Thomas I, et al., Re-conceptualizing Free Trade Agreements Through a Sustainable Development Lens. : 88.

[27] Gilmore C G, Lucey B M, McManus G M. The dynamics of Central European equity market comovements. The Quarterly Review of Economics and Finance, 2008, 48(3): 605-622.

[28] Vo X V. TRADE INTEGRATION AND INTERNATIONAL FINANCIAL INTEGRATION: EVIDENCE FROM ASIA. The Singapore Economic Review, 2018: 1-12.

[29] Greenwood J, Jovanovic B. Financial Development, Growth, and the Distribution of Income. : 50.

[30] Hall B H, Lerner J. Chapter 14 - The Financing of R\&D and Innovation. 见: B.H. Hall, N. Rosenberg. Handbook of the Economics of Innovation. North-Holland, 2010, 1: 609-639.

[31] Eggertsson G B, Robbins J A, Wold E G. Kaldor and piketty's facts: The rise of monopoly power in the united states. National Bureau of Economic Research, 2018.

[32] Barkai S. Declining labor and capital shares. The Journal of Finance, 2020, 5(75): 2421-2463.

[33] Eisfeldt A L, Falato A, Xiaolan M Z. Human Capitalists. 2018.

[34] Hall R E. The Relation between Price and Marginal Cost in U.S. Industry. Journal of Political Economy, The University of Chicago Press, 1988, 96(5): 921-947.

[35] Rogerson R. Comment on 《Accounting for Factorless Income 》. NBER Macroeconomics Annual 2018, volume 33 , 2018: 229-234.

[36] Barkai S, Benzell S G. 70 Years of US Corporate Profits. Stigler Center for the Study of the Economy and the State, New Working Paper Series, 2018(22).

[37] Wang Z, Wei S-J, Yu X, et al., Measures of Participation in Global Value Chains and Global Business Cycles. 23222, National Bureau of Economic Research, 2017.

[38] Fally T. Production staging: measurement and facts. Boulder, Colorado, University of Colorado Boulder, May, 2012: 155-168.

[39] Antràs P, Chor D. On the Measurement of Upstreamness and Downstreamness in Global Value Chains. 24185, National Bureau of Economic Research, 2018.

[40] Koopman R, Powers W, Wang Z, et al., Give Credit Where Credit Is Due: Tracing Value Added in Global Production Chains. 16426, National Bureau of Economic Research, 2010.

[41] Barkai S. Declining Labor and Capital Shares. 2019: 67.

[42] Chen W, Los B, Timmer M P. Factor Incomes in Global Value Chains: The Role of Intangibles. 25242, National Bureau of Economic Research, 2018.

[43] Lu Y, Tao Z, Zhu L. Identifying FDI spillovers. Journal of International Economics, 2017, 107: 75-90.

[44] Keller W. International trade, foreign direct investment, and technology spillovers. 见: Handbook of the Economics of Innovation. Elsevier, 2010, 2: 793-829.

[45] Baron R M, Kenny D A. The Moderator-Mediator Variable Distinction in Social Psychological Research: Conceptual, Strategic, and Statistical Considerations. : 10. 